\title{
Atomic Thunder by Liz Tynan
}

\author{
Samuel Wratten
}

James Cook University

B etween 1956 and 1963, the British government tested seven nuclear weapons on Australian soil, along with hundreds of minor tests that contaminated the land and exposed local communities to dangerous levels of radiation. They did so largely under a veil of secrecy, and it was decades before the Australian government moved to compensate affected remote Indigenous communities. Atomic Thunder tells the story of how a legacy of nuclear testing changed the face of Australia in the aftermath of the Second World War. The book traces the history of the British A-Bomb tests at Maralinga and Monte Bello from early research into the secrets of the atom through to the repercussions Australians faced for allowing the British to act unchecked on their land. Atomic Thunder skilfully untangles the history of nuclear testing in Australia by uncovering the stories of the people who helped to develop such devastating weaponry, the people who should have been holding them to account and those who suffered due to the lack of oversight. Liz Tynan exposes the many individuals and groups who failed to stand up for the interests of Australia by holding the British government in check. Tynan's skill as a journalist is apparent in her ability to take her readers seamlessly through the different stages of the Australian nuclear tests right through to the present while uncovering the stories of the people involved.

The events the book describes took place at a time when Australia was transitioning from being a British colonial outpost to an extension of American hegemony in the Pacific. Tynan suggests that the officials who allowed the British nuclear testing program to commence in Australia grew up in an Australia that considered itself a British colony under British rule. Although the Empire had been dealt a significant blow with the fall of Singapore, these men were not willing to see the sun set on an Australia under the British flag. The losses in SouthEast Asia fuelled Britain's decision to develop atomic weapons at a time when she, like all of Europe, was already facing the tremendous costs of the Second World War. At a time when the people of Britain still endured the hardships of rationing, its government saw fit to dedicate funds to the development of nuclear weapons. Struggling with finding its place in the world as the empire crumbled into a commonwealth, nuclear weapons became a way of ensuring that Britain remained a major player on the world stage. Twentieth-century anxieties surrounding the United Kingdom's place in the world contributed to the development of its modern political self-image, and many of the attitudes Liz Tynan suggests motivated Britain's nuclear program are still of influence today.

While Australian identity has largely distinguished itself from its British heritage, many of the 
colonial attitudes Tynan illustrates in Atomic Thunder continue to leave their mark on politics today. If the overwhelmingly negative response to Tony Abbott's decision to reinstate knighthoods put to rest any lingering notion of imperial nostalgia, attitudes surrounding the treatment of Aboriginal and Torres Strait Islander peoples demonstrate that Australia has not yet overcome its colonial past. Liz Tynan describes the government's complete lack of an attempt to understand the perspective of Aboriginal Australians, their culture, or the effects that nuclear testing would have on their lives, and it seems little has changed in the intervening years. Atomic Thunder depicts the encroachment of Western civilisation into Aboriginal communities of the region as having occurred alongside the story of the nuclear tests. Tynan sums up the treatment of the Aboriginal people of the area as "Colonialism in microcosm and speeded up." One of the few white people who actually understood the issues facing Aboriginal communities and how government policy would affect them was Walter MacDougall, a native patrol officer for the region, and Tynan characterises his attitudes as visionary for the time. The lessons of the Maralinga tests for public policy are many, but few have been learned. Just as the government once rounded up whole communities into camps and expected them to live more civilised - which translated to European-lives, contemporary policies such as the Northern Territory National Emergency Response, otherwise known as the Intervention, propose to solve the problems of Indigenous communities by letting white people have more control over their lives.

Atomic Thunder suggests that the key driver of British nuclear ambition was a vain effort to maintain the power and influence it had accumulated during the rise of the British Empire. The British procured the compliance of the Australian government by calling upon entrenched colonial loyalties and entertaining Australian hopes that the tests would bring greater power and prestige to Australia as well. Tynan explores the concept of empire, asking what drives a geographically and culturally distinct nation like Australia to relinquish state sovereignty to a foreign power based on little more than tradition. She calls into question not just the historical justifications for British and Australian nuclear ambitions, but also the way Australians imagine themselves in the context of the international community. Atomic Thunder forces its reader to consider whether Australia is destined to bind its fate to what Menzies identified as "great and powerful friends," or whether there is some possibility it can one day reconcile itself to its colonial past and stand on its own merits.

\section{Atomic Thunder: The Maralinga Story by Elizabeth Tynan is published by University of Queensland Press (2017). RRP \$24.95 AUD, ISBN 9781742234281.}

Atomic Thunder has won the Council for the Humanities, Arts and Social Sciences (CHASS) Australia Book Prize for 2017 and the 2017 Prime Minister's Literary Award (History). Heartfelt congratulations, Liz, from your colleagues at James Cook University and the editorial team at eTropic. 